\title{
Land Management for Agriculture After The 2010 Merapi Eruption
}

\author{
DOI: $10.18196 /$ pt.2018.078.32-38
}

\author{
Sri Nuryani Hidayah Utami ${ }^{1,2 *}$, Benito Heru Purwanto ${ }^{1,2}$, Djaka Marwasta ${ }^{1,3}$ \\ ${ }^{1}$ Centre Study for Land Resources, Universitas Gadjah Mada, Yogyakarta, Indonesia, 55281 \\ ${ }^{2}$ Faculty of Agriculture, Universitas Gadjah Mada, Yogyakarta, Indonesia, 55281 \\ ${ }^{3}$ Faculty of Geography Universitas Gadjah Mada, Yogyakarta, Indonesia, 55281 \\ *Corresponding author, email: nuryani@ugm.ac.id
}

\begin{abstract}
The great eruptions of Mount Merapi in 2010 have drawn a great deal of attention from both national and international media. The month-long eruptions killed more than 200 people, displaced over 100,000 residents, killed over 1,000 livestock and destroyed over 1,000 hectares of productive farming fields. Incidentally, agriculture is one of the livelihood sectors that suffered heavily. Further, it impacted farmers the most as they depend on farming activities as their main source of livelihood. After, the eruption, land management became based on material type and condition of the land.. Principles of land management involve the provision of appropriate environmental needs of plants, the availability of moisture, nutrients, colloidal holding nutrients, and aeration. In short, they entail the technical aspects of recovery after the eruption of plants based on the conditions of the land. Also included are crop diversification (intercropping cultivation, crops rotation, mixed farming, etc) and intensification of yard (horticulture crops, hedge rows); as well as reinforcing of core and source of cattle nutrition, for example gliricedea; fast growing and producing crops are needed but those that need high capital / major costs for planting and care are not required. Furthermore, the concept of post-eruption land arrangements needs to be formulated based on the configuration of the land which is mainly related to local circumstances such as topography, hydrology, meteorology, and natural drainage systems.

Keywords: Land management, Farming activities, Merapi eruption
\end{abstract}

\begin{abstract}
ABSTRAK
Letusan Gunung Merapi yang besar pada tahun 2010 telah menarik perhatian besar dari media nasional dan internasional. Letusan selama sebulan menewaskan lebih dari 200 orang, membuat lebih dari 100.000 penduduk mengungsi, menewaskan lebih dari 1.000 ternak dan enghancurkan lebih dari 1.000 hektar pertanian produktif lapangan. Pertanian adalah salah satu sektor penghidupan yang sangat menderita. Lebih jauh lagi, ini berdampak paling besar bagi petani karena mereka bergantung pada kegiatan pertanian sebagai sumber mata pencaharian utama mereka. Setelah letusan, pengelolaan lahan menjadi berdasarkan jenis material dan kondisi lahan. Prinsip pengelolaan lahan melibatkan penyediaan kebutuhan lingkungan yang tepat dari tanaman, ketersediaan kelembaban, nutrisi, nutrisi holdng koloid, dan aerasi. Singkatnya, memerlukan aspek teknis pemulihan setelah letusan tanaman berdasarkan kondisi tanah. Juga termasuk diversifikasi tanaman (penanaman tumpang sari, rotasi tanaman, pertanian campuran) dan intensifikasi halaman (tanaman holtikultura, barisan tanaman); serta memperkuat inti dan sumber nutrisi ternak, misalnya gliricedea; tanaman yang tumbuh cepat dan menghasilkan diperlukan tetapi mereka yang membutuhkan biaya tinggi / besar untuk penanaman dan perawatan tidak diperlukan. Selanjutnya konsep pengaturan lahan pasca-letusan perlu diformulasikan berdasarkan konfigurasi lahan yang terutama terkait dengan keadaan lokal seperti topografi, hidrologi, meteorologi, dan sistem drainase alami.
\end{abstract}

Kata Kunci: Pengelolaan lahan, Aktivitas pertanian, Erupsi merapi

\section{INTRODUCTION}

Mount Merapi is a strato type volcano located $30 \mathrm{~km}$ in North of Yogyakarta. Its peak reaches 3,000 m above sea level. Being Indonesia's most active volcano, it erupts every four years on the average. Apart from other damage, volcanic activity can disrupt the surrounding river networks by abrupt deposition and subsequent flow of large amounts of sediments. This can increase the risk of floods, including flash floods; change the planform of the river network; and destroy roads, bridges, buildings and other structures. However, the impacts are manageable to some extent. Appropriate preparation and determined mitigation efforts can not prevent the damage, but can reduce it significantly (Sumaryono, 2011).

Vulnerability of land is associated with the threat of natural disasters. Attention needs to be given to reduce the impacts through technical and 
non-technical measures. This will be a fundamental strategy in supporting the success of agriculture to be developed. This should be done in addition to land conservation efforts that can improve land productivity and sustainability of the environment.

Preparation of the carrying capacity of land zoning area slopes of Mount Merapi eruption after 2010 is intended to reduce the risk of disasters and to minimize losses. With the zoning, it is expected that farmers and ranchers in the area of the slopes of Mount Merapi can live in harmony with nature. These lands are located in the vicinity of Mount Merapi, formed from volcanic ash. Volcanic ash is the material of volcanic eruptions that is released as results of volcanoes in the form of dust, gravel, and hot stone.

The situation on the upper slopes of Mount Merapi is periodically amended following the eruption period. Given these changes, there is variability of soil characteristics at the various locations in the slopes. Soil conditions on the slopes of Mount Merapi were dominated by young earth. Young soils also vary in the period following the eruption and have both physical and chemical properties that differ. Development of land is also followed by the growth of vegetation on it, because developed land provides nutrients for plants. Land on the upper slopes of Mount Merapi consists of Regosol (Entisols and Inceptisol). Regosol land is a relatively young soil, so it has no development profile. This soil has gray to black ground color with a relatively coarse texture; it is sandy. The soil structure is also not established; it is granular. In addition to Regosol, Andisol soil is found there as well. This soil type is found in district and sub-district of Cepogo Selo. The soil is characterized by silty loam texture, with crumb or blocky structure; its bulk density is about 0.9 g.cm-3, and it has medium permeability to low organic matter, with $\mathrm{pH} 5.0$ to 5.5 ; its base saturation is high (Anonymous, 2008).
The area of Mount Merapi, which is generally a plateau region, a catchment area and being infiltrated with rain water, is excellent. Ability to retain water is affected by physical properties such as texture and presence of vegetation in the area. Utilization of the upper slopes of Mount Merapi as a conservation area should be developed and preserved. In addition to the storm water, the upper slopes of Mount Merapican also be used for forestry, national parks, or even as tourist area.

\section{MATERIALS AND METHODS}

The research was started by desk evaluation to study about the location surrounding Merapi Volcano based on existing maps (visual map of the earth, geological maps, soil maps, zoning maps of Disaster-Prone Areas of Mount Merapi issued by the Center for Volcanology and Geological Disaster Mitigation, Geological Agency, Ministry of Energy and Resources Mineral. And then field observations and sampling of ash and sand material of Merapi eruption results from various locations were carried out and then the materials obtained were analyzed in the laboratory of Departement of Soil Science, Faculty Agriculture, Universitas Gadjah Mada, Yogyakarta.

Analysis of volcanic sand and ashes include: soil $\mathrm{pH}$, Electrical Conductivity, total P, N, Si, Al, Mg, $\mathrm{Ca}, \mathrm{K}, \mathrm{Na}, \mathrm{Fe}, \mathrm{Mn}, \mathrm{Cu}, \mathrm{Zn}$ (Tan, 1996). And then the maps and recommendations were prepared.

\section{RESULTS AND DISCUSSIONS}

Material during eruption

In general, the distribution of pyroclastic deposits that consist of a mixture of granular material ash, lapilli and blocks of the volcanois strongly influenced by the amount of material, the force of gravity, and topographic areas affected by the initial eruption. The more pyroclastic material is issued, the more extensive is the distribution of the 
hot cloud. Due to gravity, the pyroclastic deposits are mainly coarse-grained (lapilli-boulders) and are more concentrated in river alleys. The deeper and more river valleys as a result of intensive vertical erosion, the distribution of pyroclastic deposits will be more limited, as it is pretty deposited in the river valley area. Conversely, if the valley of the river is a bit then the shallow pyroclastic deposits will be widespread (Bronto et al., 2003).

Table 1. Analysis of sand and volcanic ashes from Merapi eruption in 2010

\begin{tabular}{lcc}
\hline Variables & Sand & Volcanic ashes \\
\hline pH & 4.89 & 4.86 \\
EC $(\mathrm{mS})$ & 4.4 & 5.87 \\
Total N $(\%)$ & 0.003 & 0.01 \\
Available P $(\mu \mathrm{g} / \mathrm{g})$ & 199.18 & 213.18 \\
Soil water P $(\mu \mathrm{g} / \mathrm{g})$ & 156.29 & 191.28 \\
Total S $(\mu \mathrm{g} / \mathrm{g})$ & 4.58 & 4.83 \\
Total Cl $(\mu \mathrm{g} / \mathrm{g})$ & 36.83 & 6.44 \\
SiO2 $(\mu \mathrm{g} / \mathrm{g})$ & & 53.92 \\
Al2O3 $(\mu \mathrm{g} / \mathrm{g})$ & & 18.34 \\
Total $\mathrm{Mg}(\mu \mathrm{g} / \mathrm{g})$ & & 0.06 \\
Total Ca $(\mu \mathrm{g} / \mathrm{g})$ & 0.07 & 0.49 \\
Total $\mathrm{Na}(\mu \mathrm{g} / \mathrm{g})$ & 0.31 & 0.14 \\
Total K $(\mu \mathrm{g} / \mathrm{g})$ & 0.07 & 0.51 \\
Total Fe $(\mu \mathrm{g} / \mathrm{g})$ & 0.15 & 0.75 \\
Total $\mathrm{Mn}(\mu \mathrm{g} / \mathrm{g})$ & 0.66 & 0.13 \\
Total Cu $(\mu \mathrm{g} / \mathrm{g})$ & 0.01 & 39.49 \\
Total $\mathrm{Zn}(\mu \mathrm{g} / \mathrm{g})$ & 30.98 & 35.08 \\
\hline
\end{tabular}

Source: Soil Science Laboratory, Faculty of Agriculture, Universitas Gadjah Mada, 2010

\section{Agriculture}

Volcanic activity includes the formation of magma and magma discharge from the mouth of the crater which can be either in the form of the flow of molten lava or volcanic bursts of various sizes; this shapes the material in the air and falls to the earth's surface following the gravitational force that is also affected by wind direction and speed. The chemical composition and bursts of lava rock are determined by the drafters of magma (aluminum silicate of igneous rock), and material of non-magma (hydrothermal, mineral salts and non-rocks andesitic/basaltic).

The results of the analysis of the mineral contents in the ash and sand of volcanic eruption of Mount Merapi in 2010 conducted at the Department of Soil Science, Faculty of Agriculture, Gadjah Mada University are presented in Table1.

The data in table 1 showed that the ash quality is quite good; it just needs to be rinsed thoroughly to remove soluble salts in the form of base cations, aluminum, sulfate and chloride ions. The results of the analysis showed the $\mathrm{pH}$ of the Merapi volcanic ash; its sand is acidic, and the electrical conductivity is $4-5 \mathrm{mS}$. Though, agricultural crops generally can survive in soil with electricity conductivity of less than $2 \mathrm{mS}$. Agricultural crops such as vegetables and fruits like chili, watermelon, salacca, and so on died not only because of the falling leaves due to the weight of the volcanic material, but also because of the high electrical conductivity of volcanic material. However, the volcanic ash also contains elements that are beneficial to plants, dominated by the nutrient content of $54 \%$ silica. Silica is a very useful element for the rice plant. It makes rice plant stand upright, and resistant to pests and diseases (Elawad and Green, 1979; Lee et al., 1985; Osuna-Canizales et al., 1991; Seebold et al., 2000). The ash also has sulfur and chloride, which are also the nutrients that plants need. Looking at the chemical characteristics of volcanic material, it can be said that there are no problems for farmers to replant their farms, in order to mix the soil with native soil.

Rehabilitation of agricultural land is not just a matter of the chemistry or element contents inside the volcanic material, but also a physical problem. This is because it depends on the thickness of the deposits, the process of precipitation and the size 


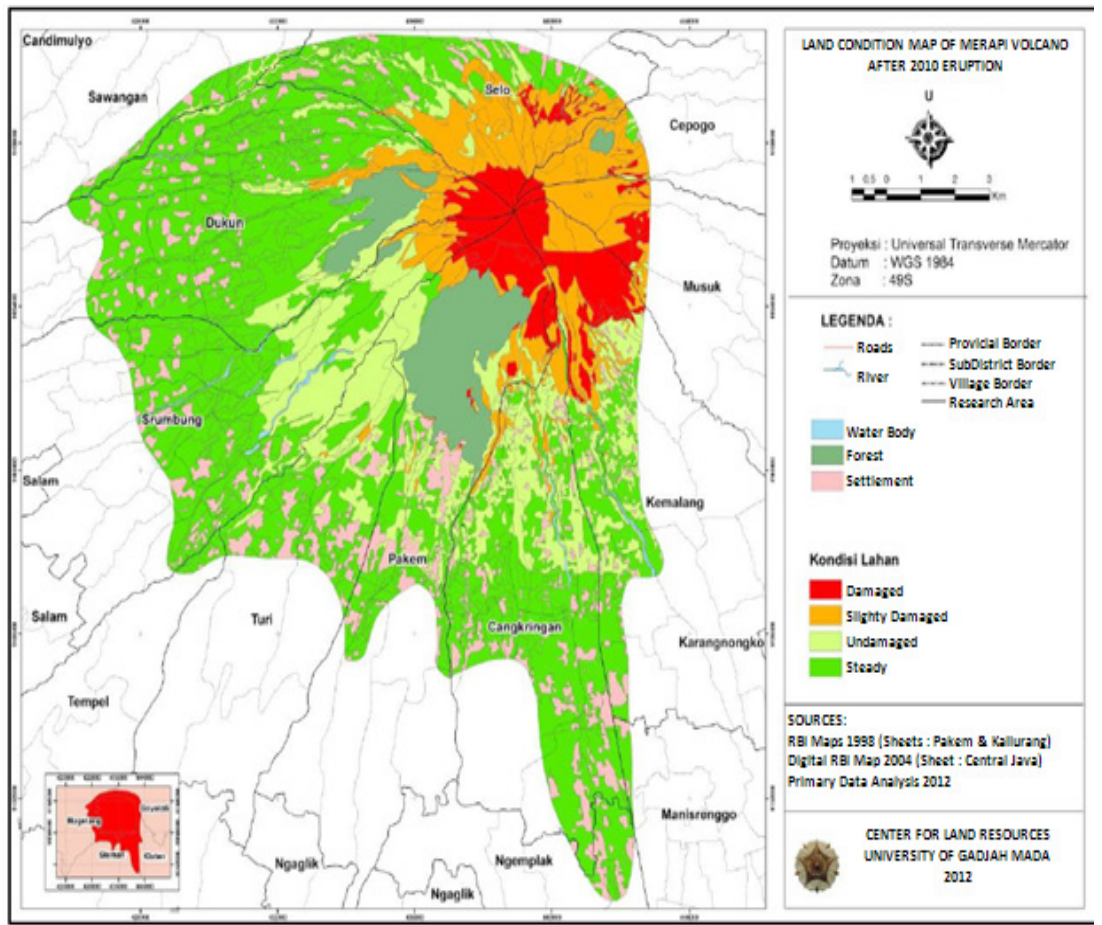

Figure 1. Recent Land Resources Condition Map of The 2nd and 3rd Danger Zone Merapi Volcano. (Center for Land Reosurces, Universitas Gadjah Mada, 2012)

of the material that is deposited orburied. Center for the Study of Land Resources, Gadjah Mada University divides the land types affected by the eruption of Merapi as follows (Utami et al., 2010).

(1) Agricultural land is buried/exposed to the direct influence of the hot cloud, as in the District of Cangkringan; the thickness of the deposits is very great, with coarse material pile of sand and gravel (Figure 2). The thickness and roughness of a pile of volcanic material show that the agricultural lands in this area are buried by new material. Investment in this area will have to wait until the soil temperature cools by rain. As the material is still loose (fragile, yet bound to a solid structure) it will be easily carried by wind or rain. So, one needs to be careful with the possibility of erosion, if the slope of the ground is high; especially for areas that are close to the trim (e.g. $5 \mathrm{~km}$ ). It should not apply to plants that are productive, but forest plants that have strong roots. If the leaves fall easily, weathering happens, unlike pine and acacia in which weathering is difficult.
(2) The land affected by a burst of volcanic material such as ash or sand and even gravel. Agricultural lands affected by ash/sand/gravel are widely distributed, such as Muntilan, Sleman, Klaten, and even some distant places like Purworejo and Bandung. If these volcanic materials cover the ground with a thickness of not more than $5 \mathrm{~cm}$, for example, in the District of Turi and Tempel, Sleman, and some districts in Srumbung, Magelang, then the soil can be directly processed as in the past; if the material is a fine dust, it can increase the content of soil nutrient. But if the volcanic material thickness is greater than $10 \mathrm{~cm}$, deep tillage of $20 \mathrm{~cm}$ is required. The addition of organic materials is very important in this area, especially if its deposits are coarse materials such as sand and gravel mixture.

(3) Agricultural land covered by the cold lava in the left or right of the river, which empties into the trim such as Boyong, Kuning, Gendol, Krasa, Code, Opak, and Progo. Cold material land could be fine to coarse, depending on the distance to the 


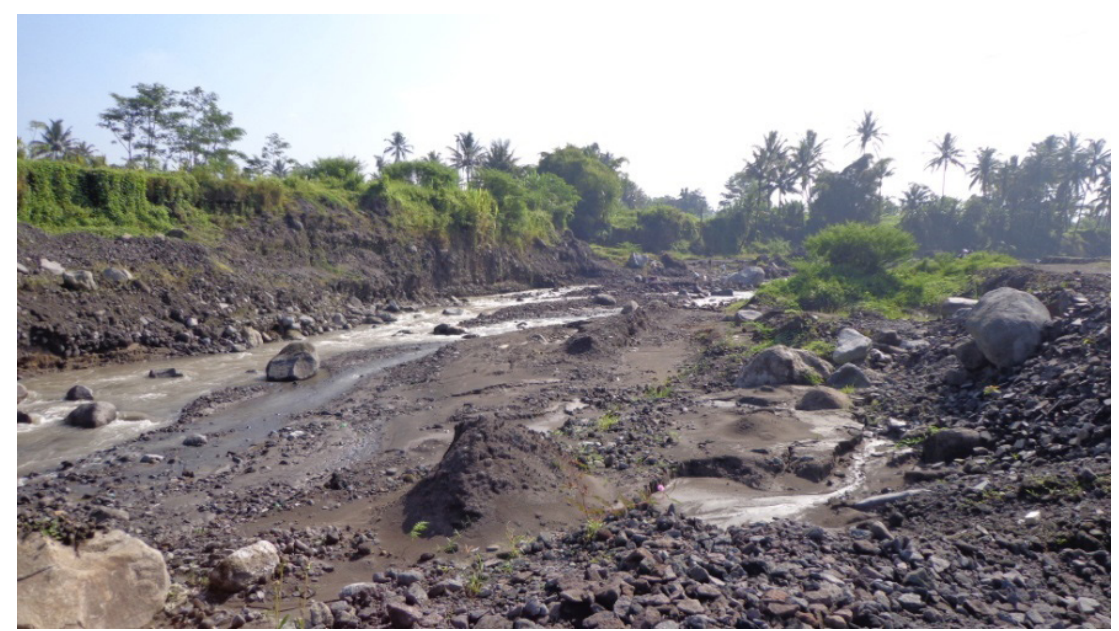

Figure 2. Agricultural land damaged by the brunt of lava and eroded by lava flows after the 2010 Merapi eruption. The agricultural land can't be planted again because it is now become part of the river.

(Private documentation by the authors, 2010)

trim. Cold lava is of course due to water-borne, so that the contents of useful elements for the plant are unwashed. So, it is necessary to understand the typology of the agricultural land, its boundaries and the characteristics of rehabilitation.

Rehabilitation of agricultural land can be accelerated by adding nutrients that plants need and the provision of manure. Soil is fertile if it contains mineral and organic materials. Mineral ingredients provide elements for plants; the nutrients can be derived from inorganic and organic fertilizers that can be supplied. Then the irrigation water needs to be prepared, so that agricultural land can be restored to normal in a short time. Truly, a very important thing is to recover as soon as the spirit of the farmers rises wakes up to cultivate the slopes of Merapi. This will further accelerate the recovery of the agricultural sector. In many places with a lot of lands, farmers cultivate their land back, and all they needed were support from the government, availability of seeds, composting counter machines, and irrigation water. Integration of livestock and agriculture will be of much help, because the cattle will make available sufficient organic fertilizer.

In short, the technical aspect of recovery after eruption is seeking plant which is suitable for the land conditions. This can easily be seen with preexisting plants. If these plants can grow well and produce, that means they are appropriate/suitable. To be more precise, they should use a Land Suitability Map. This can be done to reduce the risk of crop failure due to eruption of Merapi. One of the conditions is: crop diversification (intercropping cultivation, mixed farming, etc.) In principle, plants that are fast-growing, rapidly produce and do not require capital / major costs for planting and care should be selected. High economic value crops such as bark have high risk because generally after four years to produce well, it needs capital. On the slopes of Merapi, a highly vulnerable plant should be avoided unless there is already an existing one. Plants that require a lot of water (in number) should be avoided because of the eruption and in case of damaged water resources it needs a lot of time and capital for the recovery / rehabilitation. To further make the farmers better prepared for disasters is to get money savings and cattle. Cattle can be a sheep, cow, and poultry which dung can be utilized as manure. Intensification of the yard should be encouraged. Reinforcing the porch railing is necessary and many kinds of fruit trees and horticultural crops as well as animal food sources 


\section{MERAPI SLOPE AREA ZONING MAP 2010}

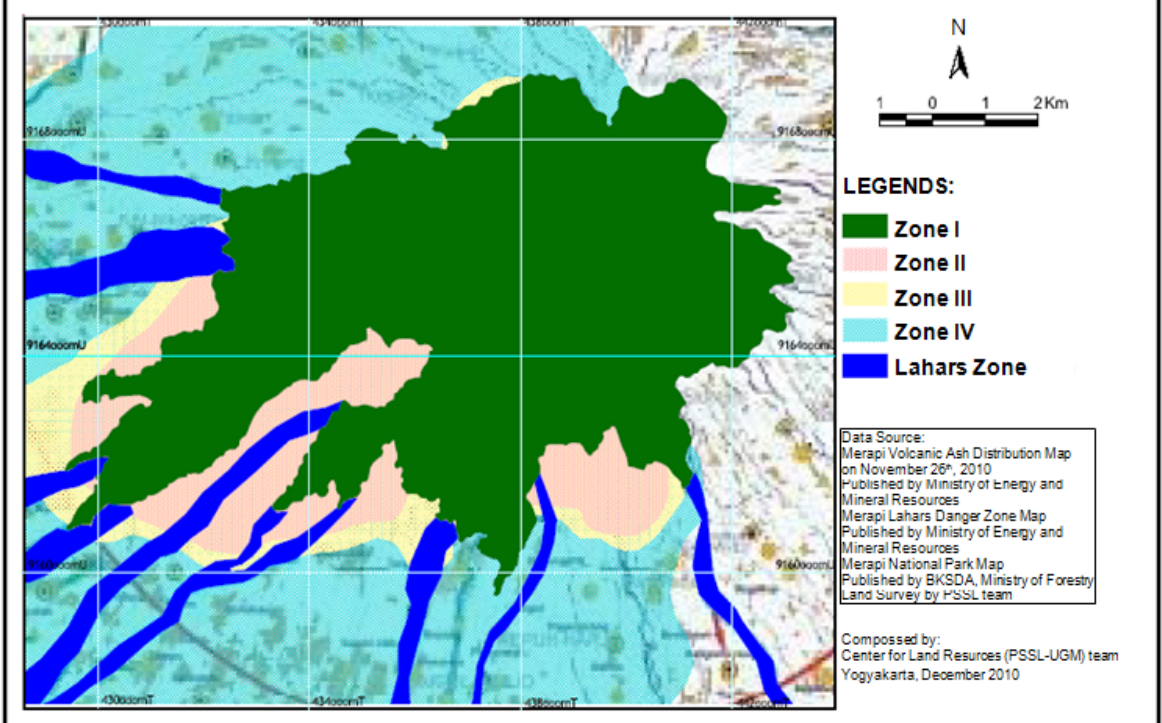

Figure 3. Merapi slope area zoning concept based on the agricultural land resources and livestock support. (Centre for Land Resources Universitas Gadjah Mada, 2010)

Note: ZONE I: National park. The forbidden zone for occupancy. ZONE II: This is hazard zone. There shoud not be public service here.
ZONE III: Residential and agricultural area ZONE IV: Residential and agricultural area such as gliricedea should be planted.

On the slopes of Merapi, agricultural application that involves low energy input is more in accordance with the conditions of hazardous eruption of the application of agricultural inputs (high energy input), with high capital. Learning from the experience of green revolution and also of intensive farming in developed countries, sustainable agriculture paradigm still using natural environment is not based anymore on the soil's ability to tolerate high input material, but rather based on elasticity (resilience) of the land to damage, if the land is used for agricultural production (Sanchez, 1994; FAO, 1995).

The government should implement policies and fiscal environment that encourage farmers to utilize germplasm of local resources, develop low-input farming systems (Low External Input Sustainable Agriculture), or real farm system according to the state of the environment and distinctive character of small farmers (FAO, 1997). Noteworthy is creating a more productive farming system integrated in marginal land, such as crop-livestock systems, crop and agro-forestry-fishery (agroforestry). One of the keys to success in implementing the new strategy is to combine traditional site-specific technology and new technology management of crops and livestock (Sutanto, 2000).

\section{Resilience of agricultural systems}

Many farms, particularly those on the southern and western flanks of Merapi, are expected to lose up to $100 \%$ of damaged crops during the current rotation. However, because of the warm climate, fertile soils and good access to water (on the lowlands and during the wet season), the farms are anticipated to recover rapidly following cessation of tephra falls, with many farmers predicting 2-3 harvests within the next 12 months. Thus, the year-round growing season contributes substantially to resilience within this agricultural system, particularly for lowland farms. Lowland farmers are therefore able to choose preferred crops, such as rice, that will maximise returns. Upland farms are 
somewhat more vulnerable during the dry season, but farmers are still able to replant immediately if required (Wilson et al., 2007, Utami et al., 2010). Upland farmers add greater diversity to their selection of cash crops to build more resilience into their farming systemsdue to the unreliable water supply in upland regions. the increased resilience also helps to reduce the impact of volcanic activity. The attitude that 'if one crop fails then others will survive' was frequently encountered by the team, with respect to crop selection practices. Wilson et al. (2007) stated that their observations supported the effectiveness of this approach, with some farms affected by heavy ashfalls showing severe damage to some crops and virtually no damage to others. For instance, chilli pepper plants would be severely affected while other crops planted between them, such as carrots, would be almost unaffected. The naturally-high resilience of agricultural systems in the Merapi area is to some extent offset by the inability of most farmers to absorb financial losses. Farming in the area is only slightly above a subsistence level and many farmers spoken to by the team considered themselves unable to absorb the loss of even one crop rotation. This level of hardship was probably a motivating cause of farmers returning to the exclusion zone after being evacuated. Many farmers reported that they had few other options, and felt that they must 'ride out' the eruption (particularly those in the upland regions) and wait for the rains to wash crops and help integrate the tephra into the soil (Wilson et al., 2007).

\section{CONCLUSIONS}

Disaster risk reduction activities can be managed properly if the nature and character of the land can be properly assessed. Disaster risk reduction activities are the only one that can be done for minimizing losses due to a natural disaster. Based on field analysis, data analysis of volcanic ash, thematic maps and the results of image analysis, and the researches belonging to the Center for Land Resources, Merapi Slopes Zoning Recommendation concept was made based on the carrying capacity of land for agriculture and animal husbandry as a post-eruption which could be seen on the Map (Figure 1, 3).

\section{ACKNOWLEDGEMENT}

We would like to thank to the Ministry of Research and Higher Education, Indonesia (RISTEKDIKTI) for giving the opportunity to conduct this research and providing budget to fund this research.

\section{REFERENCES}

Anonymous, 2008.National Park of Mount Merapi. DG PHKA. Jakarta. Bronto, S., D.S. Sayudi and G. Ho. 2003. Heat clouds slide variation and danger of Mount Merapi. Association of Indonesian geologists. Yogyakarta.

Elawad, S. H. and V. E. Green 1979. Silicon and the rice plant environment: A review of recent research. Riv. Riso 28:235-253.

FAO. 1995. The state of food and agriculture; Rome, Italy, 1997.

Sanchez, P.A. 1994. Tropical soil fertility research: towards the second paradigm. Transactions 15th World Congress of Soil Science, Acapulco. 65-88.

Lee, K. S., S. B. Ahn, G. S. Rhee, B. Y.Yeon, , and J. K. Park. 1985. Studies of silica application to nursery beds on rice seedling growth. Farm Prod. Utiliz. 27:23-27.

Seebold, K. W., L. E.Datnoff, F. J. Correa-Victoria, T. A. Kucharek, and G. H. Snyder.2000. Effect of silicon rate and host resistance on blast, scald, and yield of upland rice. Plant Dis. 84:871-876.

Sumaryono, A. 2011. Managing the Mount Merapi sediments. Center for River Basin Organizations and Management, Solo, Central Java, Indonesia www.crbom.org, info@crbom.org.

Sutanto, R. 2000. Global challenges toward food security and the role of indigenous knowledge in agriculture development. Paper presented in the Seminar " The Role of Indigeneous Knowledge for National Food Security". USD, Yogyakarta.

Tan, K.H. 1996. Soil Sampling, Preparation and Analysis. Marcel Dekker, Inc. New York.

Osuna-Canizales, F. J., S. K. De Datta, and J. M. Bonman, 1991. Nitrogen form and silicon nutrition effects on resistance to blast disease of rice. Plant Soil 135:223-231.

Utami, S.N.H., A.M. Darmanto, E. Martono, B.H. Purwanto, G. Murdjito, A. Kusumandari, R. Jayadi, D. Kastono, and Jamhari. 2010. Daya dukung kawasan lereng Merapi untuk Pertanian dan Peternakan. Laporan Penelitian Hibah Merapi. PSSL UGM.

Wilson, T.; G. Kaye, C.Stewart, and J. Cole 2007 Impacts of the 2006 eruption of Merapi volcano, Indonesia, on agriculture and infrastructure. GNS Science Report 2007/07 69p. 